The Moral Behavior of Ethicists and the Role of the Philosopher

\author{
Eric Schwitzgebel \\ Department of Philosophy \\ University of California at Riverside \\ Riverside CA 92521 \\ USA
}

December 10, 2013 


\title{
The Moral Behavior of Ethicists and the Role of the Philosopher
}

\author{
Abstract: \\ Professional ethicists appear to behave no differently than do non-ethicists of similar social \\ background. The evidence suggests that they are no likelier to donate to charity, to choose a \\ vegetarian diet, to reply to student emails, to pay conference registration fees they owe, to return \\ their library books, to vote in public elections, to stay in regular contact with their mothers, to be \\ blood or organ donors, or to behave politely at conferences. On some issues, however, such as \\ charitable donation and vegetarianism, ethicists tend to endorse more stringent ethical norms \\ than do non-ethicists. This pattern of results might fit with a view on which the role of the \\ philosopher is only to espouse and defend ethical norms, not to live according to those norms.
}




\section{The Moral Behavior of Ethicists and the Role of the Philosopher}

Professional ethicists appear to behave no differently than do non-ethicists of similar social background. However, ethicists also appear to embrace more stringent moral norms than do non-ethicists, at least on some issues. Part 1 will summarize the empirical evidence. Part 2 will discuss one possibly attractive response: that an ethicist's role is to espouse and defend moral norms, with no special obligation to live according to the norms she espouses and defends.

\section{The Moral Behavior of Ethicists.}

So far, all of the systematic empirical studies of the moral behavior of professional ethicists have been done by a single research group - the research group led by Eric Schwitzgebel, the author of this article. This will, then, be an embarrassingly self-centered review.

Our first study (Schwitzgebel and Rust 2009), examined professional philosophers’ opinions about the moral behavior of ethicists. We offered gourmet chocolate to passersby at a meeting of the Pacific Division of the American Philosophical Association in exchange for completing, on the spot, a '5 minute philosophical-scientific questionnaire'. There were two versions of the survey. One version asked respondents whether 'professors specializing in ethics tend, on average, to behave morally better, worse, or about the same as philosophers not specializing in ethics', with a seven-point response scale from 'substantially morally better' (marked 1) through 'about the same' (marked 4) to 'substantially morally worse' (marked 7). Opinion was divided: 35 per cent of respondents circled a number on the 'better' side of the scale (1-3); 46 per cent circled 4 'about the same', and 19 per cent circled a number on the 'worse' 
side. The second version asked respondents to rate the overall moral behavior of an arbitrarily (alphabetically) selected ethicist from their own department and also to rate the overall moral behavior of a similarly selected specialist in metaphysics and epistemology: 44 per cent rated the selected ethicist morally better behaved than the other selected philosopher, 26 per cent rated them the same, and 30 per cent rated the ethicist worse - a trend toward 'better' over 'worse', but not statistically significant in our sample.

We have directly examined moral behavior - or behavior that is arguably moral - using a wide variety of measures. Schwitzgebel (2009) examined the rates at which relatively obscure philosophy books - the kinds of books likely to be borrowed mostly by professors and advanced graduate students in the field - were missing from leading academic libraries in the U.S. and Britain. Ethics books were substantially more likely to be missing than other types of philosophy books, even though the two groups of books were similar in overall age, check-out rate, and holdings per library. Schwitzgebel and Rust (2010) found that ethicists and political philosophers were no more likely to vote in public elections, as measured by state records of voter participation, than were non-ethicist philosophers or professors in fields other than philosophy or political science. (Political scientists, in contrast, did vote more often than other professors.) Schwitzgebel, Rust, Huang, Moore, and Coates (2012) found that ethicists were no more likely to behave courteously at professional meetings than were other philosophers, as measured by rates of talking audibly during the formal presentation, allowing doors to slam when entering or exiting mid-session, and leaving behind cups and trash at one's seat. Audiences in environmental ethics sessions did, however, leave behind less trash. Rust and Schwitzgebel (2013) found that ethicists were no more likely than other professors to respond to email messages designed to look like queries from students. Schwitzgebel and Rust 
(forthcoming-b) found that non-ethicist philosophers were more likely to respond to a request to complete a survey when they were offered a charity incentive to do so ( $\$ 10$ to the respondent's choice of six major, well-regarded charities) than when they were not offered a charity incentive, but ethicists appeared to be unmoved by the charity incentive. Schwitzgebel (2013) found that ethicists were no more likely than other philosophers to pay their registration fees at meetings of the American Philosophical Association in the mid-2000s, when the APA relied upon an honor system for registration payment.

Schwitzgebel and Rust (forthcoming-b) examined self-reports of moral attitudes and moral behavior, across several issues, in three groups of professors in five U.S. states: philosophers specializing in ethics, philosophers not specializing in ethics, and a comparison group of other professors from the same universities. Some of the self-reports could be directly checked against objectively measured behavior, thus enabling a three-way comparison of selfreported attitude, self-reported behavior, and directly measured behavior for these three groups of professors. Schwitzgebel and Rust solicited self-reported attitudes and behavior on nine different issues: membership in one's main disciplinary academic society (such as the American Philosophical Association), voting in public elections, staying in touch with one's mother, regularly eating the meat of mammals, blood donation, organ donation, answering student emails, charitable giving, and honesty in responding to survey questions. The groups did not detectably differ in their self-reported rates of membership in disciplinary societies, in their selfreported voting rates, in their self-reported rates of blood or organ donation, in their self-reported responsiveness to student emails, or in their self-reported honesty in answering survey questionnaires. Non-philosophers reported more regular contact with their mothers than did the two groups of philosophers. Non-ethicist philosophers reported giving a lower percentage of 
their income to charity than did either ethicists or non-ethicist philosophers. And although ethicists reported eating the meat of mammals at fewer meals per week than did the other two groups, the three groups did not detectably differ in the rates at which they reported having eaten the meat of a mammal at their previous evening meal. Checking response accuracy in various ways (e.g., comparing self-reported vote rate with state recorded voting rates for the same respondents), the three groups did not appear to differ overall in the accuracy of their selfreports. Impressionistically, the aggregate result is approximately a tie. Schwitzgebel and Rust also mathematically aggregated the behavioral data in three different ways, finding no difference overall between ethicists and the other groups by any of the aggregate measures. Schwitzgebel and Rust (forthcoming-a) presents a meta-analysis of all the studies described in this section and again finds no tendency for ethicists to behave morally better or morally worse overall than other philosophers.

Schwitzgebel and Rust also examined correlations between self-reported normative attitude and both self-reported and directly measured behavior. Although ethicists showed a detectably higher correlation between attitude and behavior than did the other groups with respect to voting in public elections $(r=.36$, vs. .14 for non-ethicist philosophers and .01 for non-philosophers), they showed a detectably lower correlation between attitude and self-reported charitable giving ( $\mathrm{r}=.33$, vs. .46 for non-ethicist philosophers and .62 for non-philosophers). The aggregate attitude-behavior correlation did not detectably differ among the groups $(r=.20$ for ethicists, vs. .24 for non-ethicist philosophers and .16 for non-philosophers; all comparisons in this paragraph use Fisher's r-to-z conversion and a pairwise alpha level of .05).

The most notable group difference Schwitzgebel and Rust found was this: On several issues, ethicists appeared to endorse more stringent moral standards. Ethicists were more likely 
than other groups to rate blood donation and charitable donation as morally good, and they were more likely to rate meat-eating and failing to be an organ donor as morally bad. The results are especially striking for vegetarianism: 60 per cent of ethicists rated 'regularly eating the meat of mammals, such as beef or pork' somewhere on the 'bad' side of a 1-9 scale from 'very morally bad' to 'very morally good', compared to 45 per cent of non-ethicist philosophers and only 19 per cent of professors from departments other than philosophy $\left(\chi^{2}=64.2, p<.001\right)$. When asked 'About what percentage of income should the typical professor donate to charity? (Enter " 0 " if you think it's not the case that the typical professor should donate to charity.)', only 9 per cent of ethicists entered '0', compared to 24 per cent of non-ethicist philosophers and 25 per cent of other professors $\left(\chi^{2}=18.2, \mathrm{p}<.001\right)$; and among those not entering ' 0 ', the geometric mean was 5.9 per cent for ethicists vs. 4.8 per cent for both of the two other groups (ANOVA, F = 3.6, p = .03). However, as mentioned above, these differences in normative attitude did not detectably manifest in behavior.

\section{The Role of the Philosopher.}

If the role of the philosophical ethicist were to present her- or himself as a living model of wise conduct, these results might be alarming. However, most philosophers seem to be unalarmed and unsurprised by the results described in Part 1. Most philosophers' general idea of the role of the philosopher does not appear to be threatened by the possibility that ethicists behave overall no differently than do non-ethicists, or by the possibility that ethicists behave overall no more consistently with their espoused opinions, or by the possibility that ethicists espouse stringent moral views without tending to shift their behavior accordingly. 
I think of Randy Cohen's farewell column as ethics columnist for the New York Times Magazine. Cohen writes:

Writing the column has not made me even slightly more virtuous. And I didn't have to be.... I wasn't hired to personify virtue, to be a role model for kids, but to write about virtue in a way readers might find engaging. Consider sports writers: not 2 in 20 can hit the curveball, and why should they? They're meant to report on athletes, not be athletes. And that's the self-serving rationalization I'd have clung to had the cops hauled me off in handcuffs.

What spending my workday thinking about ethics did do was make me acutely aware of my own transgressions, of the times I fell short. It is deeply demoralizing (Cohen 2011).

In light of the vegetarianism results described in Part 1, we might consider the following scenario: An ethicist philosopher considers the question of whether it's morally permissible to eat the meat of factory-farmed mammals. She reads Peter Singer. She reads objections and replies to Singer. In light of the considerations, she concludes - as the majority of U.S. ethicists seem to - that in fact it is morally bad to eat meat. She presents the material in her applied ethics class. Maybe she even writes on the issue. However, instead of changing her behavior to match her new moral opinions, she retains her old behavior. She teaches Singer's defense of vegetarianism, both inwardly and outwardly endorsing it, and then proceeds to the university cafeteria for a cheeseburger, perhaps feeling somewhat bad about it.

To the student who sees her in the cafeteria, our philosopher says: Singer's arguments are sound. It is morally wrong of me to eat this delicious cheeseburger. But my role as a philosopher is only to discuss philosophical issues, to present and evaluate philosophical views 
and arguments, not to live accordingly. Indeed, it would not be fair to expect me to live to higher moral standards just because I am an ethicist. I am paid to teach and write, like my colleagues in other fields; it would be an additional burden on me, not placed upon them, to demand that I also live my life as a model. Before accepting such an additional demand, I would require additional compensation.

Furthermore, our ethicist continues, the demand that ethicists live as moral models would create distortive pressures on the field that might tend to lead us away from the moral truth. If I feel no inward or outward pressure to live according to my publicly espoused doctrines, then I am free to explore doctrines that demand high levels of self-sacrifice on an equal footing with more permissive doctrines. If instead I felt an obligation to live as I teach, I would feel considerable pressure to avoid highly self-sacrificial doctrines. I would be highly motivated to avoid concluding that the wealthy should give most of their wealth to charity or that people should never lie out of self-interest. The world is better served if the intellectual discourse of moral philosophy is undistorted by such pressures, that is, if ethicists are not expected to live out their moral opinions.

Such a view of the role of the philosopher is very different from the view of most ancient ethicists. Socrates, Confucius, and the Stoics sought to live according to the norms they espoused and invited others to judge their lives as an expression of their doctrines.

It is an open and little discussed question which is the better vision of the role of the philosopher. 


\section{References:}

Cohen, Randy (2011) 'Goodbye’, New York Times Magazine, Feb. 27 issue, http://www.nytimes.com/2011/02/27/magazine/27FOB-Ethicist-t.html

Rust, Joshua, and Eric Schwitzgebel (2013) 'Ethicists' and Nonethicists' Responsiveness to Student Emails: Relationships among Expressed Normative Attitude, Self-Described Behavior, and Empirically Observed Behavior', Metaphilosophy, 44, 350-371.

Schwitzgebel, Eric (2009) 'Do Ethicists Steal More Books?’ Philosophical Psychology, 22, 711725.

Schwitzgebel, Eric (2013) 'Are Ethicists Any More Likely to Pay Their Registration Fees at Professional Meetings?' Economics \& Philosophy, 29, 371-380.

Schwitzgebel, Eric, and Joshua Rust (2009) 'The Moral Behaviour of Ethicists: Peer Opinion’, Mind, 118, 1043-1059.

Schwitzgebel, Eric, and Joshua Rust (2010) 'Do Ethicists and Political Philosophers Vote More Often Than Other Professors?' Review of Philosophy and Psychology, 1, 189-199.

Schwitzgebel, Eric, and Joshua Rust (forthcoming-a), 'The Behavior of Ethicists' in W.

Buckwalter and J. Sytsma (eds.) Blackwell Companion to Experimental Philosophy.

Schwitzgebel, Eric, and Joshua Rust (forthcoming-b) 'The Moral Behavior of Ethics Professors:

Relationships among Self-Reported Behavior, Expressed Normative Attitude, and Directly Observed Behavior, Philosophical Psychology.

Schwitzgebel, Eric, Joshua Rust, Linus Ta-Lun Huang, Alan T. Moore, and Justin Coates (2012)

'Ethicists' Courtesy at Philosophy Conferences', Philosophical Psychology, 25, 331-340. 